\title{
A new chapter: hematopoietic stem cells are direct players in immunity
}

Junke Zheng ${ }^{1}$, Chun Song ${ }^{2,3}$ and Cheng Cheng Zhang ${ }^{1 *}$

\begin{abstract}
Several lines of evidence support the hypothesis that hematopoietic stem cells (HSCs) directly interact with the immune system and have potential for immune privilege. Although the microenvironment or niche provides protection for HSCs from immune attack, HSCs are also capable of interacting with the immune system as signal "providers" and signal "receivers". On the one hand, HSCs display surface immune inhibitory molecules to evade the attack from the innate and adaptive immune systems; on the other hand, HSCs are capable of directly sensing the signals from the immune system through their surface receptors. Thus, HSCs are important direct players in the immune system.
\end{abstract}

Keywords: stem cell, hematopoietic stem cells, immunity, immunology, CD47, CD274, infection, inflammation, niche

\section{Introduction}

The immune properties of pluripotent stem cells and tissue-specific stem cells have been attracting research interest. Based on the observation that embryonic stem (ES) cells express low levels of HLA class I and hardly any HLA class II proteins, it was initially suggested that ES cells are not recognized by the host immune system. However, well-designed experiments by Swijnenburg et al. clearly demonstrated that human ES cells were rejected upon transplantation into immune-competent recipient mice [1]. A novel study by Zhao et al. also showed that induced pluripotent stem (iPS) cells could trigger an immune response even in syngeneic recipients [2]. Therefore, it appears that pluripotent ES cells and iPS cells are not immune privileged. By contrast, some adult stem cells, such as mesenchymal and amnion stem cells are immune privileged to a certain extent. These cells are capable of avoiding rejection in intra- and even inter-species transplantation through the production of immunosuppressive molecules $[1,3]$.

Hematopoietic stem cells (HSCs) are responsible for the daily production of all blood and immune cells in the body and have been widely used in transplantation to

\footnotetext{
* Correspondence: Alec.Zhang@UTSouthwestern.edu

'Departments of Physiology and Developmental Biology, University of Texas Southwestern Medical Center, 5323 Harry Hines Boulevard, Dallas, Texas 75390, USA

Full list of author information is available at the end of the article
}

treat patients with leukemia, lymphoma, some solid cancers, and autoimmune diseases [4]. Although freshly isolated HSCs are known to have a very slim possibility of escape from immune rejection upon allogeneic transplantation, current evidence suggests that in vivo the HSC niche provides an immune-privileged site for HSCs. Moreover, HSCs per se also possess certain potential for immune privilege through the regulation of the expression of surface immune molecules. This short review, does not intend to cover the entire topic of the roles of HSCs in immunity; rather it seeks to provide an update of the recent progress toward the understanding of how HSCs survive immune-mediated elimination and how they contribute to immunity.

\section{HSCs in niches: immune privilege offered by regulatory} $T$ cells

In vivo, stromal cells and other cells form a complex microenvironment for HSCs that controls their multiple fates, including quiescence, apoptosis, and migration as well as the cell divisions that lead to formation either of daughter HSCs or of lineage-committed progenitors that are capable of limited proliferation. Currently, we know of the existence of several types of cells that form bone marrow HSC niches [5]. The endosteal HSC niche contains osteoblasts as the main supportive cell type for maintenance of hematopoiesis [6,7]. The vascular HSC 
niche is mainly composed of sinusoidal endothelial cells [8]. More recently, it was suggested that these two types of cells may establish a compound niche $[9,10]$. In addition, SDF-1 abundant reticular (CAR) cells [11], CD146expressing subendothelial stromal [12], Nestin ${ }^{+}$mesenchymal stem cells [13], macrophages [14,15], and the sympathetic nervous system [16] have also been demonstrated to represent components of HSC niches [5].

A recent elegant study by Fujisaki et al. using highresolution in vivo imaging demonstrated that regulatory $\mathrm{T}$ cells (Treg) colocalize with HSCs in the endosteal area in the bone marrow to protect HSCs from immune attack [17]. IL-10 produced by these Treg cells plays an essential role in this immune protection. This novel finding suggests that the HSC niche not only specifies an environment to control the cell fates of HSCs, but it may also provide an immune-privileged site for HSCs [17].

\section{CD47: innate immunity of HSCs}

Whereas the niche offers protection for HSCs from immune attack, HSCs are capable of migrating in and out of the niche [18], which drastically increases the possibility that they will interact with the immune system. It is evident that HSCs outside of the niche apparently are capable of protecting themselves from innate macrophage phagocytosis.

CD47, also known as integrin-associated protein, binds to the signal regulatory protein alpha on macrophages and inhibits phagocytosis. Weissman's group showed that it is expressed on freshly isolated bone marrow HSCs at a relatively low level, suggesting that the possibility of the potential interaction between HSCs and the innate immune system within the stem cell niche is small. When HSCs are activated by potent inflammatory signals and mobilize into circulation, the CD47 level is dramatically upregulated on the surface of HSCs [19]. Similarly, CD47 is also upregulated on a variety types of blood cancer and solid cancer cells [20]. It was suggested that the increased expression of CD47 on the surface of mobilized HSCs and cancer cells protects these cells from phagocytosis [20].

\section{CD274: adaptive immunity of HSCs}

In addition to evading the potential attack from the innate immune system, HSCs also have tricks that protect them against the adaptive immune system. CD274 (B7-H1 or PD-L1) is a member of the B7 family that is expressed on dendritic cells, activated immune cells, and parenchymal cells under certain condition and on cells in immune-privileged sites such as eyes and placenta where it inhibits $\mathrm{T}$ cell or innate activation [21,22]. CD274 is also selectively expressed by various cellular components in the tumor microenvironment, where it inhibits tumor- specific $\mathrm{T}$-cell immunity by inducing $\mathrm{T}$ cell apoptosis and delaying rejection [21].

We recently provided evidence demonstrating that HSCs possess the ability to regulate their surface expression of CD274 in order to evade the rejection by the acquired immune system [23]. We showed that CD274 is expressed on freshly isolated bone marrow HSCs at a low level in vivo [23]. These are similar to the scenario of CD47. Surprisingly, after in vitro culture, HSCs upregulate the surface expression of CD274 10-fold, which efficiently inhibits host $\mathrm{T}$ cell proliferation upon allograft transplantation [23]. These observations clearly indicate that ex vivo culture significantly modulates the immunogenicity of stem cells. Therefore, in striking contrast to pluripotent stem cells, HSCs have modulatable immune privilege that can overcome allogeneic immune barrier, and HSCs can directly participate in adaptive immunity.

Fiorina et al. demonstrated that CD274 is upregulated on mouse splenic $\mathrm{Lin}^{-} \mathrm{Kit}^{+}$hematopoietic cells after the treatment of an antagonist of chemokine CXCR4 [24], suggesting that the CD274 level on phenotypic hematopoietic progenitors can be increased upon mobilization. Whether the expression of CD274 on primitive and functional HSCs or blood cancer cells can be physiologically regulated in vivo and its biological significance warrants further investigation. Moreover, the future identification of additional immune molecules whose alterations (either up or down) can regulate allograft acceptance will enable the complete resolution of the issue of immune rejection in allogeneic transplantation.

\section{HSC activation by infection}

While the existence of niche and the expression of immune inhibitors on HSCs enable HSCs to evade immune attack, it is also clear that HSCs can directly respond to pathogen-specific infection through systematic cytokine stimulation from both innate and adaptive immune signals. Several classes of signaling receptors expressed on HSCs that bind to cytokines or infectious ligands directly participate in the infection response: IFN receptors [25-27], TNF receptor [28-30], and Tolllike receptors (TLR) [31-33] (see review by Goodell's group [34]). In general, the infection or inflammatory signals activate HSCs and chronically lead to accelerated differentiation at the expense of loss of HSC potency [27]. The differentiation produces immune effector cells that counteract the initial infection. By contrast, the aberrant IFN and TNF signaling are associated with myelodysplastic syndrome and bone marrow failure [34]. We predict that additional immune-related surface signaling receptors also regulate the cell fates of HSCs. For example, the identification of the receptors for Angiopoietin-like proteins (Angptls) [35-38] will enable us to 
elucidate the effects of inflammatory Angptls on HSCs (unpublished data).

\section{Model of the interplay between HSCs and the immune system}

Based on these recent progress, we propose a model for the interaction between HSCs and the immune system. Within the niche, HSCs are protected by Treg cells from potential immune attack. Outside the niche, HSCs are capable of directly interacting with the immune system through surface immune molecules for "out" signaling and "in" signaling (Figure 1).

The "out" signaling is mediated by factors such as CD47 and CD274 that inhibit attack from the innate immunity and adaptive immunity responses, respectively. Based on the results discussed here, we hypothesize that homeostatic HSCs express low levels of surface immune suppressors, and the levels of these suppressors can be induced by stress or immune signals. These immune suppressors may thus modulate HSC immunogenicity and, therefore, contribute to the "immune privilege" of HSCs. This regulatable "immune privilege" should be advantageous to HSCs as it should allow these important stem cells to rapidly adjust to altered environmental conditions or protect them from excessive immune activation/inflammation or potential autoimmune disorders.

The stimulatory "in" signaling from inflammation activates $\mathrm{HSCs}$ and induces differentiation through surface receptors including TLR, TNFR, IFNR, and others. This activating "in" signaling should be counter-balanced by the environmental cues within the stem cell niche, which maintain the quiescence and stemness of HSCs. The continuing investigation of this area may open up a new scientific field - the immunology of stem cells. We speculate that a common mechanism exists for regulation of immune signals in some other types of stem cells. It will be interesting to study the immunology of stem cells by investigating the roles of surface immune molecules and receptors on ES cells, iPS cells, other adult stem cells, and cancer stem cells.

\section{Open questions}

The following questions must be addressed to provide new insights into the understanding of immunology of stem cells:

\section{"Out" signals \\ "In" signals}

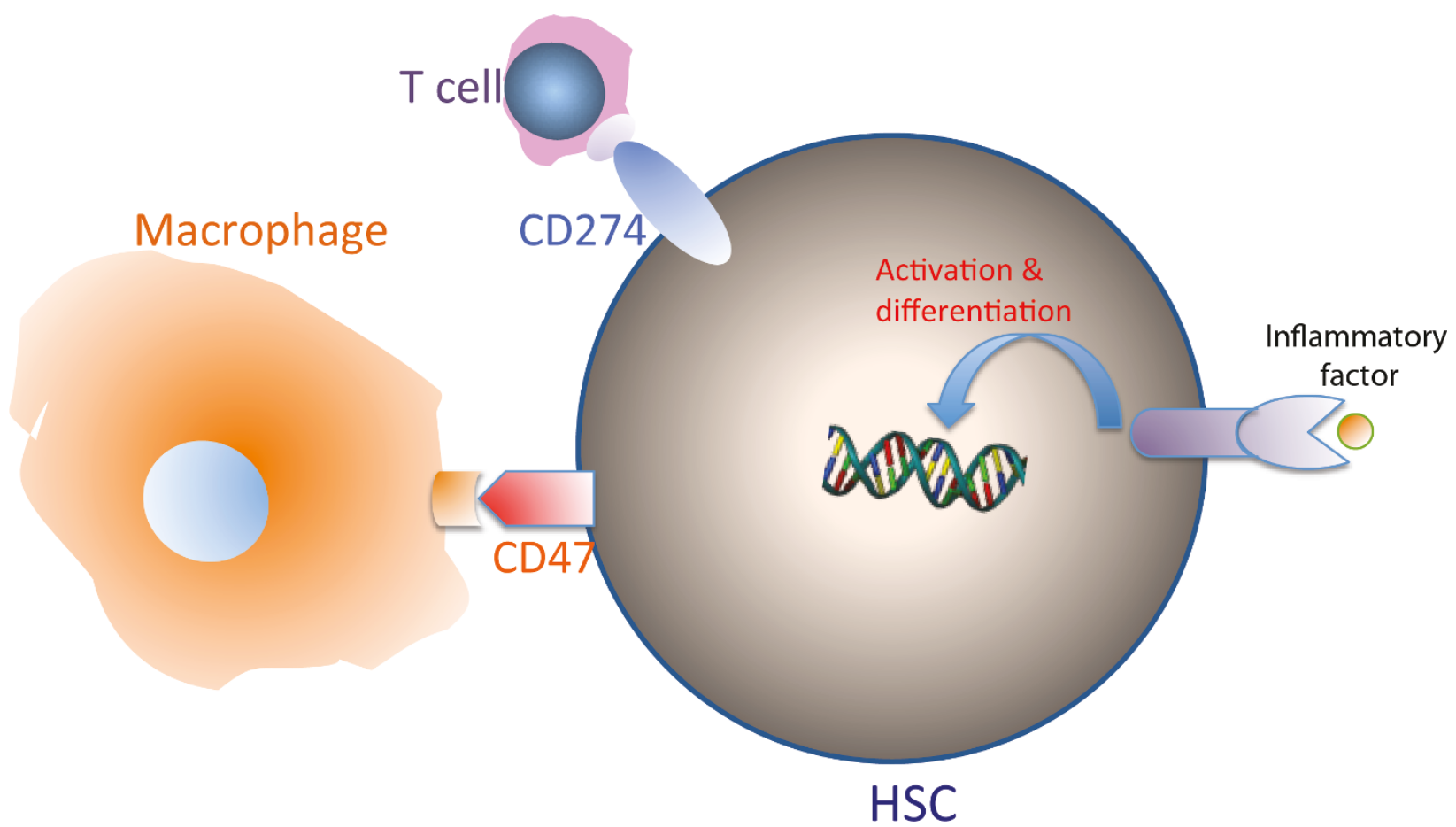

Figure 1 A model of the interplay between HSCs and the immune system. HSCs express surface immune molecules for "in" signaling and "out" signaling that directly dialog with the immune system. Whereas the "out" signaling, mediated by surface molecules such as CD47 and CD274, inhibits attack from the innate immunity and adaptive immunity responses, respectively, the stimulatory "in" signaling from inflammation activates HSCs and induces differentiation through surface receptors including TLR, TNFR, IFNR, and others. 
1) What surface immune molecules in addition to CD47 and CD274 are expressed on HSCs and other stem cells that modulate the immunogenicity of stem cells?

2) Do HSCs express immune stimulatory molecules? Probably yes. If so, what are their functions in modulating other immune cells?

3) How is the expression of immune surface molecules regulated in vivo? What is the mechanism for the potential upregulation of immune suppressors and downregulation of immune stimulators? Do surface immune molecules change their expression on HSCs upon mobilization, infection, and in extramedullary organs?

4) HSCs can interact with immune system as signal providers ("out" signaling) and as signal receivers ("in" signaling). What is the connection between the "in" signaling and "out" signaling? Can "in" signaling modulate the type and magnitude of "out" signaling and vice versa? The study of CD274 may provide more insight into this question. For example, CD274 is not only a ligand for PD-1 and CD80 (thus providing "out" signaling) but is also a counter-receptor of PD-1 that may deliver the reverse "in" signaling.

5) Can HSCs sense signals from the immune system to attenuate their activation? Does this help maintain their stemness?

6) Do human and mouse stem cells have similar immunology? For example, do CD274 and other surface immune molecules play similar roles in both species?

7) Does the aberrant immune property of stem cells cause diseases?

8) What are the expression and functions of surface immune molecules and receptors on other stem cells including ES cells, iPS cells, other tissue specific stem cells, and cancer stem cells?

\section{Conclusion}

Recent evidence suggests that HSCs are immune privileged within the in vivo bone marrow niche. Nevertheless, HSCs are also capable of interacting with the immune system as signal "providers" and signal "receivers". As signal providers, HSCs display surface immune inhibitory molecules to suppress the innate and adaptive immune systems. As signal receivers, HSCs directly sense systematic immune signals through their surface receptors and change their cell fates in response to the altered immune environment. HSCs thus directly interact with the immune system. The data discussed here mark the start of a series of investigations that may open up a new field - the immunology of stem cells.

\section{List of abbreviations}

Angptls: angiopoietin-like proteins; ES cells: embryonic stem cells; HSCs: hematopoietic stem cells; iPS cells: induced pluripotent stem cells; TLR: tolllike receptor; Treg: regulatory $T$ cells.

\section{Acknowledgements}

CCZ is the Michael L. Rosenberg Scholar in Biomedical Research at UT Southwestern Medical Center. Support to CCZ was from NIH grant K01 CA 120099, American Society of Hematology Junior Faculty Award, American Heart Association 09BGIA2230372, DOD PR093256, CPRIT RP100402, March of Dimes Foundation 5-FY09-146, Robert A. Welch Foundation 1-1701, and the Gabrielle's Angel Foundation.

\section{Author details}

'Departments of Physiology and Developmental Biology, University of Texas Southwestern Medical Center, 5323 Harry Hines Boulevard, Dallas, Texas 75390, USA. ${ }^{2}$ Shandong University and National New Drug R\&D Center in Shandong, 44 West Wenhua Road, Shandong University, Jinan 250012, China. ${ }^{3}$ Kemedicine Pharmaceutical LLC, 37 Science Center Road, Changping, Beijing 102206, China.

\section{Authors' contributions}

CCZ, JZ, and CS wrote the manuscript. All authors read and approved the final manuscript.

\section{Competing interests}

The authors declare that they have no competing interests.

Received: 14 August 2011 Accepted: 6 October 2011

Published: 6 October 2011

\section{References}

1. Swijnenburg RJ, Schrepfer S, Govaert JA, Cao F, Ransohoff K, Sheikh AY, Haddad M, Connolly AJ, Davis MM, Robbins RC, Wu JC: Immunosuppressive therapy mitigates immunological rejection of human embryonic stem cell xenografts. Proc Natl Acad Sci USA 2008, 105(35):12991-12996.

2. Zhao $T$, Zhang $Z N$, Rong $Z, X u$ Y: Immunogenicity of induced pluripotent stem cells. Nature 2011, 474(7350):212-215.

3. Salem HK, Thiemermann C: Mesenchymal stromal cells: current understanding and clinical status. Stem Cells 2010, 28(3):585-596.

4. Bryder D, Rossi DJ, Weissman L: Hematopoietic stem cells: the paradigmatic tissue-specific stem cell. Am J Pathol 2006, 169(2):338-346.

5. Lymperi S, Ferraro F, Scadden DT: The HSC niche concept has turned 31. Has our knowledge matured? Ann N Y Acad Sci 2010, 1192(1):12-18.

6. Z Zhang J, Niu C, Ye L, Huang H, He X, Tong WG, Ross J, Haug J, Johnson T, Feng JQ, Harris S, Wiedemann LM, Mishina Y, Li L: Identification of the haematopoietic stem cell niche and control of the niche size. Nature 2003, 425(6960):836-841.

7. Calvi LM, Adams GB, Weibrecht KW, Weber JM, Olson DP, Knight MC, Martin RP, Schipani E, Divieti P, Bringhurst FR, Milner LA, Kronenberg HM, Scadden DT: Osteoblastic cells regulate the haematopoietic stem cell niche. Nature 2003, 425(6960):841-846.

8. Kiel MJ, Yilmaz OH, Iwashita T, Terhorst C, Morrison SJ: SLAM family receptors distinguish hematopoietic stem and progenitor cells and reveal endothelial niches for stem cells. Cell 2005, 121(7):1109-1121.

9. Hooper AT, Butler JM, Nolan DJ, Kranz A, lida K, Kobayashi M, Kopp HG, Shido K, Petit I, Yanger K, James D, Witte L, Zhu Z, Wu Y, Pytowski B, Rosenwaks Z, Mittal V, Sato TN, Rafii S: Engraftment and reconstitution of hematopoiesis is dependent on VEGFR2-mediated regeneration of sinusoidal endothelial cells. Cell Stem Cell 2009, 4(3):263-274.

10. Xie Y, Yin T, Wiegraebe W, He XC, Miller D, Stark D, Perko K, Alexander R, Schwartz J, Grindley JC, Park J, Haug JS, Wunderlich JP, Li H, Zhang S, Johnson T, Feldman RA, Li L: Detection of functional haematopoietic stem cell niche using real-time imaging. Nature 2009, 457(7225):97-101.

11. Sugiyama $T$, Kohara $H$, Noda M, Nagasawa $T$ : Maintenance of the hematopoietic stem cell pool by CXCL12-CXCR4 chemokine signaling in bone marrow stromal cell niches. Immunity 2006, 25(6):977-988.

12. Sacchetti B, Funari A, Michienzi S, Di Cesare S, Piersanti S, Saggio I, Tagliafico E, Ferrari S, Robey PG, Riminucci M, Bianco P: Self-renewing 
osteoprogenitors in bone marrow sinusoids can organize a hematopoietic microenvironment. Cell 2007, 131(2):324-336.

13. Mendez-Ferrer S, Michurina TV, Ferraro F, Mazloom AR, Macarthur BD, Lira SA, Scadden DT, Ma'ayan A, Enikolopov GN, Frenette PS: Mesenchymal and haematopoietic stem cells form a unique bone marrow niche. Nature 2010, 466(7308):829-834

14. Chow A, Lucas D, Hidalgo A, Mendez-Ferrer S, Hashimoto D, Scheiermann C, Battista M, Leboeuf M, Prophete C, van Rooijen N, Tanaka M, Merad M, Frenette PS: Bone marrow CD169+ macrophages promote the retention of hematopoietic stem and progenitor cells in the mesenchymal stem cell niche. J Exp Med 2011, 208(2):261-271.

15. Winkler IG, Sims NA, Pettit AR, Barbier V, Nowlan B, Helwani F, Poulton IJ, van Rooijen N, Alexander KA, Raggatt $L$, et al: Bone marrow macrophages maintain hematopoietic stem cell (HSC) niches and their depletion mobilizes HSCs. Blood 2010, 116(23):4815-4828.

16. Katayama Y, Battista M, Kao WM, Hidalgo A, Peired AJ, Thomas SA, Frenette PS: Signals from the sympathetic nervous system regulate hematopoietic stem cell egress from bone marrow. Cell 2006, 124(2):407-421.

17. Fujisaki J, Wu J, Carlson AL, Silberstein L, Putheti P, Larocca R, Gao W, Saito TI, Lo Celso C, Tsuyuzaki H, Sato T, Cote D, Sykes M, Strom TB, Scadden DT, Lin CP: In vivo imaging of Treg cells providing immune privilege to the haematopoietic stem-cell niche. Nature 2011, 474(7350):216-219

18. Marquez-Curtis LA, Turner AR, Sridharan S, Ratajczak MZ, JanowskaWieczorek A: The ins and outs of hematopoietic stem cells: studies to improve transplantation outcomes. Stem Cell Rev 2011, 7(3):590-607.

19. Jaiswal S, Jamieson CH, Pang WW, Park CY, Chao MP, Majeti R, Traver D, van Rooijen N, Weissman IL: CD47 is upregulated on circulating hematopoietic stem cells and leukemia cells to avoid phagocytosis. Cell 2009, 138(2):271-285

20. Jaiswal S, Chao MP, Majeti R, Weissman IL: Macrophages as mediators of tumor immunosurveillance. Trends Immunol 2010, 31(6):212-219.

21. Zou W, Chen L: Inhibitory B7-family molecules in the tumour microenvironment. Nat Rev Immunol 2008, 8(6):467-477.

22. Francisco LM, Sage PT, Sharpe AH: The PD-1 pathway in tolerance and autoimmunity. Immunol Rev 2010, 236:219-242.

23. Zheng J, Umikawa M, Zhang S, Huynh H, Silvany R, Chen BP, Chen L, Zhang CC: Ex vivo expanded hematopoietic stem cells overcome the MHC barrier in allogeneic transplantation. Cell Stem Cell 2011, 9(2):119-130.

24. Fiorina $P$, Jurewicz M, Vergani A, Petrelli A, Carvello M, D'Addio F, Godwin JG, Law K, Wu E, Tian Z, Thomas G, Kovarik J, La Rosa S, Capella C, Rodig S, Zerwes HG, Sayegh MH, Abdi R: Targeting the CXCR4-CXCL12 axis mobilizes autologous hematopoietic stem cells and prolongs islet allograft survival via programmed death ligand 1. J Immunol 2011, 186(1):121-131.

25. Essers MA, Offner S, Blanco-Bose WE, Waibler Z, Kalinke U, Duchosal MA, Trumpp A: IFNalpha activates dormant haematopoietic stem cells in vivo. Nature 2009, 458(7240):904-908.

26. Sato $T$, Onai $N$, Yoshihara $H$, Arai $F$, Suda T, Ohteki T: Interferon regulatory factor- 2 protects quiescent hematopoietic stem cells from type I interferon-dependent exhaustion. Nat Med 2009, 15(6):696-700.

27. Baldridge MT, King KY, Boles NC, Weksberg DC, Goodell MA: Quiescent haematopoietic stem cells are activated by IFN-gamma in response to chronic infection. Nature 2010, 465(7299):793-797.

28. Zhang Y, Harada A, Bluethmann H, Wang JB, Nakao S, Mukaida N, Matsushima K: Tumor necrosis factor (TNF) is a physiologic regulator of hematopoietic progenitor cells: increase of early hematopoietic progenitor cells in TNF receptor p55-deficient mice in vivo and potent inhibition of progenitor cell proliferation by TNF alpha in vitro. Blood 1995, 86(8):2930-2937.

29. Rebel VI, Hartnett S, Hill GR, Lazo-Kallanian SB, Ferrara JL, Sieff CA: Essential role for the p55 tumor necrosis factor receptor in regulating hematopoiesis at a stem cell level. J Exp Med 1999, 190(10):1493-1504.

30. Rezzoug F, Huang Y, Tanner MK, Wysoczynski M, Schanie CL, Chilton PM, Ratajczak MZ, Fugier-Vivier IJ, Ildstad ST: TNF-alpha is critical to facilitate hemopoietic stem cell engraftment and function. J Immunol 2008, 180(1):49-57.

31. Nagai $Y$, Garrett KP, Ohta S, Bahrun U, Kouro T, Akira S, Takatsu K, Kincade PW: Toll-like receptors on hematopoietic progenitor cells stimulate innate immune system replenishment. Immunity 2006, 24(6):801-812.

32. Sioud $M$, Floisand $Y$, Forfang $L$, Lund-Johansen F: Signaling through tolllike receptor $7 / 8$ induces the differentiation of human bone marrow CD34+ progenitor cells along the myeloid lineage. J Mol Biol 2006, 364(5):945-954.

33. Kim JM, Kim NI, Oh YK, Kim YJ, Youn J, Ahn MJ: CpG oligodeoxynucleotides induce IL-8 expression in CD34+ cells via mitogen-activated protein kinase-dependent and NF-kappaBindependent pathways. Int Immunol 2005, 17(12):1525-1531.

34. Baldridge MT, King KY, Goodell MA: Inflammatory signals regulate hematopoietic stem cells. Trends Immunol 2011, 32(2):57-65.

35. Zhang CC, Kaba M, Ge G, Xie K, Tong W, Hug C, Lodish HF: Angiopoietinlike proteins stimulate ex vivo expansion of hematopoietic stem cells. Nat Med 2006, 12(2):240-245.

36. Hato T, Tabata M, Oike $Y$ : The role of angiopoietin-like proteins in angiogenesis and metabolism. Trends Cardiovasc Med 2008, 18(1):6-14.

37. Zhang CC, Kaba M, lizuka S, Huynh H, Lodish HF: Angiopoietin-like 5 and IGFBP2 stimulate ex vivo expansion of human cord blood hematopoietic stem cells as assayed by NOD/SCID transplantation. Blood 2008, 111(7):3415-3423.

38. Zheng J, Huynh H, Umikawa M, Silvany R, Zhang CC: Angiopoietin-like protein 3 supports the activity of hematopoietic stem cells in the bone marrow niche. Blood 2011, 117(2):470-479.

doi:10.1186/2045-3701-1-33

Cite this article as: Zheng et al:: A new chapter: hematopoietic stem cells are direct players in immunity. Cell \& Bioscience 2011 1:33.

\section{Submit your next manuscript to BioMed Central and take full advantage of:}

- Convenient online submission

- Thorough peer review

- No space constraints or color figure charges

- Immediate publication on acceptance

- Inclusion in PubMed, CAS, Scopus and Google Scholar

- Research which is freely available for redistribution

Submit your manuscript at www.biomedcentral.com/submit
C) Biomed Central 